\title{
Developments and contributions in the study of La Rioja dinosaur footprints (Spain)
}

\section{Félix PÉREZ-LORENTE}

Universidad de La Rioja. Edificio CT. Madre de Dios 51-53. 26006 Logroño. España; felix.perez@unirioja.es

Pérez-Lorente, F. 2017. Developments and contributions in the study of La Rioja dinosaur footprints (Spain). [Evolución y aportaciones del estudio de las huellas de dinosaurio de La Rioja (España)]. Spanish Journal of Palaeontology, 32 (1), 171-184.

\begin{abstract}
In this paper the study of dinosaur tracks of La Rioja, which began in 1970, is presented as an example of knowledge development, achievements, and events occurring around a paleontological resource having strong media impact. Fieldwork, research, and dissemination since the publication of the first scientific works have been accompanied by activities to protect sites and consider them as natural and cultural heritage. Finally it is shown how a paleontological resource has also led to the development of the tourist infrastructure in the area.
\end{abstract}

Keywords: Palaeontological heritage, dinosaur, footprints, La Rioja.

\section{RESUMEN}

El estudio de las huellas de dinosaurio de La Rioja, que comenzó en 1970, se presenta como ejemplo de evolución del conocimiento, logros y acontecimientos acaecidos alrededor de un bien paleontológico de fuerte impacto mediático. Desde la publicación del primer artículo científico, el trabajo de campo, la investigación y la divulgación han ido acompañados de actividades de protección física de los yacimientos y de declaración y promoción de los mismos como patrimonio natural y cultural. Finalmente también se muestra como un bien paleontológico ha propiciado el desarrollo de las estructuras turísticas de la zona

Palabras clave: Patrimonio paleontológico, huellas, dinosaurios, La Rioja. 


\section{INTRODUCTION}

Since 1971, when the first study was published on dinosaur tracks of La Rioja, there have been more than 200 articles, books, communications, abstracts and conferences related to these tracks as well as to their protection and conservation.

During this time the techniques of study and diagnosis have been refined so that the ultimate objective of the early works (dinosaur identification) is no longer the main goal in the study of the new sites or the review of the old sites. The tracks are simply marks left by animals while living, i.e. movement imprints conditioned by the behaviour of the trackmaker, the environment, and the rock composition on which they are preserved: the mark of an activity (Sarjeant, 1990).

Three working groups related to the Museo de San Telmo (San Sebastián), the Autonomous University of Madrid and the University of La Rioja (formerly University College of Logroño/Zaragoza University) have made studies on the footprints and have also developed parallel activities, such as planned excavations. The third group emerged from the fusion of three different ones: the Museum of Sabadell, an amateur team from Logroño (see Brancas et al., 1979) and the University College of Logroño. This team, finally the University of La Rioja team, has promoted annual university activities of work camps, summer courses, and conference cycles.

The ichnological sites of La Rioja are also considered natural and cultural heritage. Inseparable from the advances and discoveries made by research teams in $\mathrm{La}$ Rioja, tourism has developed in relation to the footprints and the conception of paleontological heritage. Outcrops with footprints have been declared protected by two specific commissions, one on land use (Special Plan for Protection of Dinosaur Footprints in La Rioja), and another on protecting cultural heritage (consideration as areas of Resources of Cultural Interest, Historical Sites).

The amount and variety of activities and the number of participants involved is large enough to account for the impact of these sites, which have been the basis of the current development of tourism in the area. The involvement of universities, scientific institutions (Institute of Riojan Studies, University of La Rioja) and governmental departments in the development of the activities has been fundamental.

\section{GEOLOGICAL SETTING, FIELD CAMPAIGNS, AND METHODS}

The dinosaur footprint sites found in La Rioja occur on fluviatile and lake-shore sediments of the Cameros Basin
(Fig. 1). This basin extends into the neighbouring provinces of Burgos and Soria, and its age ranges from Kimmeridgian to Albian. The basin infill was divided (Tischer, 1966) into five groups (Groups of Tera, Oncala, Urbión, Enciso, and Oliván, from the mid-Kimmeridgian to middle-late Albian [Doublet, 2004]), all of them with footprints, of which the most productive in La Rioja is the Enciso Group, dated to the Barremian-Albian.

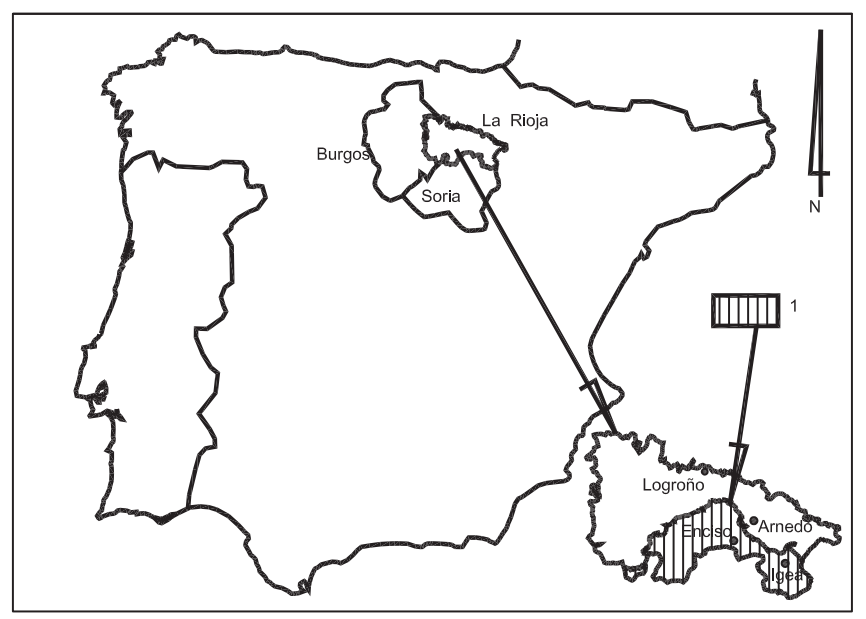

Figure 1. Location of the area occupied (1, vertical lines) by the Cameros Basin in La Rioja.

The first studies were published in 1971 (Museum of Sabadell) by two researchers (Casanovas \& Santafé, 1971). Two other teams, who had started their exploration in 1976 also published their findings (Brancas et al., 1979; Viera \& Torres, 1979).

The first authorized excavations (University College of La Rioja team) began in 1980 at two highly productive sites (Barranco de Valdecevillo and La Virgen del Campo sites). Authorized excavations continued with work camps and summer courses until 2014, after which there has been no further university activity of this type (conferences, summer courses and work camps). Participants undertook the excavation, cleaning, and reticulation of the site. Data and photographs were referenced using a grid with a mesh of $5 \times 5 \mathrm{~cm}$ superimposed on the footprints. Since 2001 these activities have become conservation site work camps.

\subsection{Background}

The footprints were discovered in 1971, when the first citation appears in a scientific journal (Casanovas \& Santafé, 1971). However, other publications date to 1966 (?), when a newspaper (El Correo Español-El Pueblo Vasco) in Logroño (Pérez-Lorente, 2015) published a story mentioning the tracks. The geologists Alfonso Meléndez and Moisés Ponce de León saw them in the field, at least 
those on the site of La Cuesta de Andorra. Brancas et al. (1979) mentioned that Blas Ochoa was the first to identify the footprints and that Rafael Brancas "realizando las denuncias y explotaciones de pirita de Ambas Aguas y las de lignitos de Préjano... se percató de las citadas huellas" and in 1960 made the first casts in La Cuesta de Andorra and Barranco de Valdecevillo. In fact, the marks to which we refer were known by the locals as footprints, although not attributed to dinosaurs but to a diverse group of animals. The locals talked about them before any mention was published.

The first place in Spain where dinosaur footprints were identified was Valencia and the second La Rioja (Table 1). Nonetheless, the origin of the footprints from Valencia has been questioned and they have been reinterpreted as the intersection of three tubular traces (Gámez \& Belinchón, 2013). The most recent and last footprint findings were in Murcia (Table 1).

Table 1. Chronological data and publication reference on dinosaur-footprint discovery in Spain.

\begin{tabular}{ll}
\hline \multicolumn{1}{c}{ Location (by region) } & \multicolumn{1}{c}{ Reference } \\
\hline $\begin{array}{l}\text { Comunidad Valenciana } \\
\text { (Rincón de Ademuz) }\end{array}$ & Lapparent et al. (1965) \\
$\begin{array}{l}\text { La Rioja (Cameros) } \\
\text { Principado de Asturias (Costa } \\
\text { asturiana) }\end{array}$ & Casanovas \& Santafé (1971) \\
Andalucía (Sierra del Pozo) & García Hernández (1978) \\
Cataluña (Vall d'Ager) & Llompart (1979) \\
Castilla y León (Soria) & Aguirrezabala \& Vera (1980) \\
Aragón (Galve) & Casanovas et al. (1984) \\
País Vasco (Bilbao) & Moratalla et al. (1994) \\
Murcia (Yecla) & Pérez-Lorente et al. (2006) \\
\hline
\end{tabular}

\section{THE FOOTPRINTS}

\subsection{Footprint features}

At the beginning of our work all the tracks were thought to be real steps that recorded the autopod sole of dinosaurs. From 1989, on analysing new findings and restudying the previously published ones, it appeared that many of the La Rioja dinosaur footprints are not the true footprints. In fact, some of the prints of the same trackway have ichnotaxonomic characters belonging to different ichnogroups (cf. Romero-Molina et al., 2003a). This led to: 1) the study of the behaviour of mud during print formation (Romero Molina et al., 2001); 2) the introduction of new concepts relating to structures (Table 2) associated with the footprints (Allen, 1997; Gatesy, 2003; Manning, 2004;
Boutakiout et al., 2006); 3) the use of terms (Table 2) regarding the fidelity of the prints or the type of surface on which they are being examined (Hitchcock, 1858; Fornós et al., 2002; Lockley, 1991; Requeta et al., 2006-7; GarcíaRaguel et al., 2009).

Table 2. Footprint features and structure denominations (cf. García Raguel et al., 2009) used in the modern description of footprints. The structures describe and relate the authopodium action and the response of the geological sedimentary structures.

\begin{tabular}{ll}
\hline \multicolumn{1}{c}{ Regarding } & \multicolumn{1}{c}{ Structure denomination } \\
\hline skin & direct, indirect \\
& true footprints, stamp, hollow, natural \\
print types & cast, subtrack, undertrack (gosh mark, \\
& transmitted print) \\
& outline footprint, wall, shaft, sole, \\
& extrusion rim, lateral fold, drag fold, \\
& axial downfold, dead zone, skid or \\
slide marks, skim marks, tension \\
cracks (circular, radial), slash-like \\
footprint morphology \\
& toemark retroversion, narrow cleft, \\
& collapse. \\
& study surface, tracking surface, \\
& original surface, deformed surface \\
\hline
\end{tabular}

The ichnite study involves the original shape of the foot and the formation of the footprint (Sarjeant, 1990): 1) in the first, or original shape of the foot, anatomical characteristics of the foot (visible or inferred) are defined and, 2) in the second, a) the autopod movements (Gatesy et al., 1999; Romano \& Whyte, 2012) in each of the phases of the footprint formation (Thulborn \& Wade, 1989), and b) the behaviour, or properties of the soil (Pérez-Lorente, 2001), i.e. the exceptional processes which follow the footprints (soil resistance [during printing], foot movement [on entering and leaving the mud], and the behaviour of the walls of the footprint and the filling of the hole) refer to the animal, its movements and the environment in which they were formed.

\subsection{Theoretical basis for the classification of the footprints in La Rioja}

In 1969 the classification of dinosaurs was far simpler than today. Very few skeletal remains of their autopodia were known, so that all traces discovered in La Rioja (Casanovas \& Santafé, 1971, 1974) were allocated to the bipedal dinosaur taxa described (Iguanodon, Megalosaurus). As the footprints were attributed to known fossil vertebrates, great precision was not needed in reproducing the prints 
and their outlines were painted white without special care concerning the thickness of the boundary line. Traces of bipedal dinosaurs, which were the only ones so far discovered in La Rioja, should have long and slender, or short and wide digit marks.

Haubold (1971), who had compiled dinosaur footprints described until that time around the world, specified and synthesized the ichnotaxonomic classification (Table 3) of Hitchcock (1836 and later) and Lull (1953), and the terminology and observations of Sternberg (1926), Peabody (1948, 1959), Baird (1952), Heyler \& Lessertiseur (1963), and Casamiquela (1964). The subsequent palaeoichnological studies, both of isolated sites and ichnological synthesis (Moratalla et al., 1988; Casanovas et al., 1989), called for greater precision in the description of the prints, the examination of their trackways, and their parataxonomic allocation.

Table 3. First dinosaur footprint classification used by the University of La Rioja team, based on Haubold (1971).

\begin{tabular}{l|l|l|l|l|l}
\hline & $\begin{array}{l}\text { Ordo } \\
\text { Saurischia }\end{array}$ & $\begin{array}{l}\text { Subordo Theropoda } \\
\text { Subordo Prosauropoda } \\
\text { Subordo Sauropoda }\end{array}$ & (1) & $\begin{array}{l}\text { Morpho- } \\
\text { Family }\end{array}$ & Ichnogenera \\
\cline { 2 - 5 } $\begin{array}{l}\text { Subclassis } \\
\text { Archosauria }\end{array}$ & $\begin{array}{l}\text { Ordo } \\
\text { Ornithischia }\end{array}$ & Subordo Ornithopoda & $\begin{array}{l}\text { Family } \\
\text { Iguanodontidae } \\
\text { Morpho-Family } \\
\text { Tetrapodosauridae } \\
\text { Family } \\
\text { Hadrosauridae }\end{array}$ & Ichnogenera \\
\hline
\end{tabular}

(1) Between Ichnogenus and Subordo, there are intermediate ichnotaxonomic groups (infraordo, superfamily, and others; e.g. Subordo Theropoda, Infraordo Carnosauria, Superfamily Megalosauroidea, Ichnogenus Eutynichnium).

Part of the study of the La Rioja ichnites is based on numerical data from the footprints and trackways. Absolute measurements, however, do not always serve to establish classification criteria. Although there are large and small dinosaurs, size differences do not necessarily identify different dinosaur species or genera. Words such as "large", "small", and "medium", or even expressions such as "relatively large" or "relatively small" lack objectivity. Sternberg (1926) used proportions (z/l or stride length/footprint length) to establish the slimness of the extremities. Table 4 shows the data on the footprints and trackways as well as the relationships that Casanovas et al. (1989) used and which have continued to be used (Pérez-Lorente, 2001, 2015).

No rules or criteria, which have been accepted by all palaeoichnologists have been established to make a parataxonomic classification of dinosaur footprints, (Romero-Molina et al., 2003a). Sarjeant (1989) established 10 basic criteria to eliminate inaccuracies in classifying footprints, and then raised the question of the relationship between the footprints and the formation process (Sarjeant, 1990).
Table 4. Metric and morphological data, and symbols used (La Rioja University team publications) in the description and identification of dinosaur footprints and trackways.

\begin{tabular}{l|l|l}
\hline \multirow{2}{*}{ metric data } & footprint & $\begin{array}{l}\text { footprint length (1), width (a); } \\
\text { digit: length (I, II, III, IV), } \\
\text { interdigital angle or divarication } \\
\left(\mathrm{I}^{\wedge} \mathrm{II}^{\wedge} \mathrm{III} \mathrm{I}^{\wedge} \mathrm{IV}\right)\end{array}$ \\
\cline { 2 - 3 } & $\begin{array}{l}\text { pace length (P), stride length } \\
\text { (z), pace angle (Ap), trackway } \\
\text { deviation (Ar), trackway width } \\
\text { (Lr), footprint orientation (O) }\end{array}$ \\
\hline \multirow{2}{*}{$\begin{array}{l}\text { morphologic } \\
\text { data }\end{array}$} & $\begin{array}{l}\text { digit proportions (long-short, narrow-width, } \\
\text { mexasony), digital pads (number, sharp- } \\
\text { blunt termination [nails, claws, hooves]); heel } \\
\text { (protruding, rounded, bilobate); footprint type } \\
\text { (digitigrade, plantigrade, semiplantigrade) }\end{array}$ \\
\hline
\end{tabular}

In the parataxonomical classification of footprints, it must be established that the holotypes of the ichnogenera are defined on stamps or tracks that are a true reflection of the sole of the foot (Brown, 1999) and must be based on biomorphic and morphometric criteria (Romero-Molina et al., 2003a), namely the shape and the absolute as well as relative dimensions of the prints. The trackmaker is deduced from: the number of digits, whether it has webbed digital pads, the shape and relative size of the digits and heel, the type of nails, interdigital angles, and sometimes the metatarsal shape and dimensions. The footprints are not usually symmetrical due to the arrangement of the digits and the right footprints are often easily distinguished from the left ones. For the description and assignment to an ichnogroup, either the most representative ichnite of each trackway, or the characters of the ideal footprint deduced from the trackway is chosen. In the publications, the footprints are represented by giving at least the outline or a boundary line (Thulborn, 1990). Peabody (1955) indicated that the characters of each new ichnogenus or ichnospecies must be seen at least in three footprints of the same trackway.

The basis used for the classification of dinosaur footprints in La Rioja is primarily biomorphic (RomeroMolina et al., 2003a), based on the work of the authors mentioned in the previous section, completed with the specifications of Demathieu (1980, 1986b), Leonardi (1987), and Thulborn (1990).

In La Rioja, saurischian and ornitischian traces attributable to theropod, sauropod, ornithopod, and thyreophoran dinosaurs have been cited (cf. Pérez-Lorente, 2015). Besides footprints from dinosaurs, traces of turtles, crocodiles, pterosaurs, birds and fish have also been described (Moratalla, 1993; Ezquerra \& Pérez-Lorente, 2003; Costeur et al., 2011). 


\subsection{Ichnotypes defined in La Rioja}

The greatest difficulty for classifying dinosaur footprints of La Rioja is the inability to assign each print to a particular dinosaur species or genus. The problem is compounded when totally different footprints are in a trackway made by the same dinosaur (i.e. that the same dinosaur left footprints having characters typical of different trackmakers). Differences may be due to the reaction of the mud, so it was considered that before defining a footprint, it had to be proved that it was a stamp and not a deformed footprint or an undertrack.

The action of the dinosaur leaves real traces (stamps or not) for later fossilization and a series of impressions and footmarks, which are called undertracks, subtracks and overtracks (cf. Pérez-Lorente, 2015). In addition to these features, are direct structures (formed in contact with the skin of the foot) and indirect structures, some of which are subsequent to the foot leaving the mud. Sometimes it is difficult to deduce whether an ichnite is a stamp, even when it leaves a faithful reproduction of the sole of the foot.

Nevertheless, we have defined several ichnogenera in La Rioja: 1) Brachyguanodontipus prejanensis Moratalla 1993, characterized by its large size and spread digits, has never been formally described, 2) Hadrosaurichnoides igeensis Casanovas, Ezquerra, Fernández, Pérez-Lorente, Santa Fé, Torcida 1993a, an ornithopod with a webbed pes, 3) Theroplantigrada encisensis Casanovas, Ezquerra, Fernández, Pérez-Lorente, Santa Fé, Torcida 1993b, a theropod with a webbed pes, and 4) Riojapodus amei Díaz-Martínez 2013, a theropod footprint characterized by highly developed digit II claw (this species has never been formally described).

\section{THE TRACKWAY. INDIVIDUAL BEHAVIOUR}

A trackway is the sequence of three or more consecutive footprints left by the same dinosaur. The word "rastrillada" was the first used in Spanish to define sequences of steps of a dinosaur (Casamiquela, 1964). "Pista" is another word that is used to define the same, but some palaeoichnologists prefer to distinguish and use "pista" for invertebrate track marks. While the characters of isolated footprints indicate the autopodium shape and the movement in and out of standing in the mud, trackways evidence gait, speed, and even the behaviour of some dinosaurs.

Long trackways (Table 5) contain a good deal of information and statistical confirmation of repeated features (sometimes only in the footprints of one side). The number of footprints from a trackway in La Rioja is variable. A theropod trackway with 19 tracks at the site of the Virgen del Campo is assumed to be of a carnivorous dinosaur attacking a herbivore (1LVC16-12) is (PérezLorente et al., 2001). The 21 ornithopod footprints of the AND1 (La Cuesta de Andorra site) trackway (PérezLorente, 2015) have been attributed to an old or sick dinosaur. The sinusoid march, which appears in all the long trackways is deduced from an ornithopod trackway (BLC1) of the Barranco de la Canal site, as well as the paradox that the largest ornithopod dinosaurs are not the fastest (Casanovas et al., 1995; Pérez-Lorente et al., 2001; Pérez-Lorente, 2015). A quadrupedal dinosaur trackway of 36 footprints (VA3) in the Barranco de Valdecevillo site shows such an abrupt change in direction and speed that can be interpreted as a response to such a strong stimulus that the change catches it wrong-footed (Pérez-Lorente, 2015). The trackway with most footprints (42) is of a theropod type (1LP17, La Pellejera site) (Requeta et al., 2006-7).

Table 5. Number of footprints and locomotion behaviour deduced from the longest trackways of La Rioja.

\begin{tabular}{llll}
\hline Trackway & $\begin{array}{c}\text { No. of } \\
\text { footprints }\end{array}$ & \multicolumn{1}{c}{ Site } & \multicolumn{1}{c}{ Hypotheses } \\
\hline $\begin{array}{l}\text { LVC12 y } \\
\text { LVC16 }\end{array}$ & 19 & $\begin{array}{l}\text { La Virgen del } \\
\text { Campo }\end{array}$ & $\begin{array}{l}\text { Theropod (carnivore) } \\
\text { attacking an ornithopod } \\
\text { (herbivore) }\end{array}$ \\
AND1 & 21 & $\begin{array}{l}\text { La Cuesta de } \\
\text { Andorra }\end{array}$ & Old or sick ornithopod \\
BLC1 & 31 & La Canal & $\begin{array}{l}\text { Sinusoid trackway: a } \\
\text { lame ornithopod moving } \\
\text { slowly. }\end{array}$ \\
VA13 & 36 & $\begin{array}{l}\text { Barranco de } \\
\text { Valdecevillo }\end{array}$ & $\begin{array}{l}\text { Sauropod trackway. } \\
\text { Frightened dinosaur? }\end{array}$ \\
\hline
\end{tabular}

Long trackways lasting about half a minute reflect considerable features of the movement of the dinosaurs, such as an unsure or halting gait, speed variation and possible jumping, and changes in direction of wrong-footed quadruped dinosaurs.

\subsection{Bipedal trackways. Two supports on the ground}

Speed calculations of bipedal dinosaur sequences with three or more steps have been made since 1989 in La Rioja (Casanovas et al., 1989). The speed is calculated with the formulas of Alexander (1976), Demathieu (1986a) and Thulborn (1990).

Later, the gait abnormalities that could be deduced from a number of footprints were analysed (cf. PérezLorente, 2015): a) four footprints (three paces) show the 
variation related to laterality, lameness, foot deformities or defects; b) with five footprints the displacement direction is established; c) the speed variation and irregular movement is deduced from six footprints (five paces); d) with seven footprints the trajectory is deduced to be curved or straight; e) from eight footprints the sinusoidal trajectories differ.

Repetition and periodicity of the characters or their variations validate some hypotheses. It has been postulated that the bipedal trackways having one greater pace length than the other (Valdeté site, VLD-R1 trackway, and Barranco de la Canal site; BLC1 trackway) were produced by limping dinosaurs or by those with laterality (Lockley et al., 1994; Casanovas et al., 1995; Pérez-Lorente, 2015). In Barranco de la Canal (BLC1) it has been deduced that lameness is caused because one foot has a deformity or injury (Razzolini et al., 2015). Repetition has also been used to ensure that certain footprints are from webbed feet, because the supposed interdigital marks (membranes) are repeated in all footprints (Casanovas et al., 1993b).

Regarding the behaviour deduced from trackways, there is one (El Villar-Poyales site, EVP12 trackway) of a dinosaur whose feet lost contact with the ground as it began to swim (Casanovas et al., 1993b; Pérez-Lorente et al., 2001; Pérez-Lorente, 2015) and another (La Virgen del Campo site, 4LVC17 trackway) of a swimming dinosaur (Ezquerra et al., 2007; Pérez-Lorente, 2015) in which only marks of the tips of toenails sliding in the mud are printed. At the same site, next to the second example of a swimming dinosaur (4LVC17), there are two trackways (4lLVC15 and 4LVC16) of a semiswimming crocodile (Ezquerra \& Pérez-Lorente, 2003; Pérez-Lorente, 2015). Finally, at the site of Las Losas, there are dinosaurs changing gait (LL22) that supports the metatarsus in some footprints but not in others (RomeroMolina et al., 2003b).

In addition, as mentioned above, from the long bipedal trackways, it has been deduced that they are not straight and that large bipedal dinosaurs are not the ones that walked the fastest.

\subsection{Trackways with tail drag. Three supports on the ground}

Dinosaurs did not drag their tail on the ground apart from exceptional cases. In the normal position tail dragging was not possible, so the animal must have been lying flat on the ground or squatting (e.g. when entering or exiting the water [Ellenberger, 1974]). Tail marks always accompany anomalous trackways as in footprints with metatarsal and/ or hallux marks.

Dinosaurs left the mark of the tail in at least three trackways in La Rioja (Moratalla, 1993; Casanovas et al., 1993c; Pérez-Lorente, 2015), two on the site of Los Cayos (LCB2 R1, LCB2-R5), and one on that of Peñaportillo
(PP150). In these trackways, the mark of the tail is a third point of support that is added to the two elements that make up the sequence of footprints (left and right feet). In La Rioja, the data provided by the third point have been used to investigate the type of bipedal gait of the dinosaur (sauriform or aviform) and the tail length (Casanovas et al., 1993c).

\subsection{Quadruped trackways. Four supports on the ground}

The variety of quadrupedal gaits is enormous. Not only can walking, trotting, and running gaits be distinguished, but even in the walking gait the amble pace, primitive alternate pace, and evolved alternate pace are distinguished (Demathieu, 1970, 1987). In the study of such quadruped trackway superposition or overlap (Peabody, 1959) must be taken into account, which in vertebrates depend on the difference between the functional limb length and the distance between the girdles. In the quadruped gait, if the overlap is primary, three dependent parameters must be considered: the glenoacetabular distance (i.e. the distance between the glenoid and acetabular girdles or centres of rotation of the fore and hind limbs), the length (height) of the limbs; and the type of walking. If two of these factors are known, the third can be deduced in the case of walking. From the sauropod trackways of La Rioja (El Sobaquillo site, SVA1 trackway; Valdecevillo site, VA13 trackway) it has been deduced that these dinosaurs were moving with an ambling gait (Casanovas et al., 1997).

\section{THE SITE. TRACKWAY ASSOCIATIONS}

In the same way that footprints are associated in a trackway, the trackways are associated with each other at a site. The deductions on the meaning of such associations must be made with caution. The association of the same ichnotype trackways, parallel or not, may be the result of three constraints: habitat, natural barriers and herd behaviour (García-Ortiz \& Pérez-Lorente, 2014). A group of the same type of dinosaurs walking together will leave parallel trackways, but a group of animals adapted to an environment, such as the boundary of a lake, will also leave trackways parallel to the water line, even if they walked at different times. Sometimes groups (herds) of dinosaurs of the same type are so large that what they leave behind is a chaos of overlapping and deformed footprints.

Pérez-Lorente (2003a) and García-Ortiz \& PérezLorente (2014) have summarized the types of theropod and ornithopod trackway associations and chaos of footprints left by the passage of herds of herbivorous dinosaurs (sauropods and ornithopods) in La Rioja. 
Noteworthy associations in La Rioja are two sets of parallel trackways (Valdecevillo site, VL9, VL10 and VL11 trackways, and Peñaportillo site, PP144, PP145, PP147, PP148 and PP149 trackways) that can be interpreted as parental, with two adults and a baby in the first, and two adults and three babies in the second (PérezLorente et al., 2001; Pérez-Lorente, 2015). It is also possible that a litter of 8-9 dinosaurs were responsible for the parallel trackways in the Barranco de Valdebrajés site in which all palaeoichnologists have recognized the herd behaviour of small bipedal dinosaurs (Aguirrezabala et al., 1985; Casanovas et al., 1991; Lockley et al., 1998). Finally, larger associations have been found that would be compatible with extended families, hunting groups (1LP8, 1LP9, 1LP10, in the Era del Peladillo), and small sauropod groups, which are perhaps insufficiently developed to join a major herd of adult sauropods (1SM, San Martin site).

Not all the footprints in an outcrop are of dinosaurs that passed at the same time, nor do they have to be of the same type of trackmaker. To avoid errors in interpreting the sites, the palaeontologist musts take into account the timing and the similarity of autopodial anatomical features. The first refers to the time of passage of each dinosaur, and the second to the similarity of the autopodia of different dinosaurs, which perform the same function in all individuals. The coexistence of footprints of carnivorous and herbivorous dinosaurs in the same outcrop with no sign of a struggle, or dinosaurs swimming and walking in the same tracking surface are indicators of the time separation between them. The time interval in which the footprints of the dinosaurs are marked on the top of a layer is, at least in some sites, very large. Moreover, differences in anatomical details among feet of some trackmakers from different species or genera that trod the same surface are minimal or absent, both for ornithopods and certain theropod dinosaurs.

The timing accounts for the definition of the study surface (Requeta et al., 2006-7), because the outcrop surface is not always the same stratification surface. At the site of La Pellejera (1LP) four tracking surfaces (Pérez-Lorente, 2015) have been identified on four nonisochronous stratification surfaces. The study surface is often an erosional surface that eliminated the tracking surface of the footprints it contains.

Synsedimentary structures, or events, sometimes serve to separate the passage of each dinosaur. There are synsedimentary landslides in the Era del Peladillo that deform or fully or partially efface some footprints made before them, while later ones are printed on the overlying rocks. Landslides are ubiquitous in both siliciclastic and carbonate beds.

\section{KNOWN FOOTPRINT CONTENTS AND POSSIBILITIES IN LA RIOJA}

The number of footprints (or trackways) that have been studied, inventoried and catalogued is not indicative of the real contents. The calculation of the total number of outcropping footprints is impossible at present. La Rioja has over 1,000 trackways, an uncounted number of groups and herds, and isolated footprints, i.e. about 10,000 catalogued footprints at about 140 sites distributed throughout 20 municipalities (Pérez-Lorente, 2003a).

The footprints in the La Rioja sector of the Cameros Basin occupy almost the entire exposed surface of strata in a radius of about $10 \mathrm{~m}$. Only sedimentary factors (beds deposited in relatively deep lakes), and erosion of the rock (strata tops are not consistent in their composition or the intense fracturing and jointing) limit the presence of footprints. In the Grupo de Urbión strata, it is normal to find natural casts (the filling of the footprint hollows) scattered in the field, or on the lower stratification surface of sandy layers, but there are virtually no footprints on the upper surface of rocks because they are friable (PérezLorente, 2002).

In calculating existing and outcropping footprints, we must take into account the expandable sites (Hernández Medrano et al., 2006). In some cases, we have calculated the number of tracks that could be exposed easily (Table 6). The calculations of excavated areas and those which could be excavated of large sites of La Canal-Peñaportillo, La Pellejera, Los Cayos, La Virgen del Campo and El Peladillo, provide the following information: the sum of all the studied area $\left(8,200 \mathrm{~m}^{2}\right)$ contains 4,988 footprints; this surface can be expanded without technical problems to $23,200 \mathrm{~m}^{2}(8,200+15,000)$. If the ichnite density is even throughout, it would leave about 9,000 footprints.

Table 6. Current extension and minimum expansion area by cleaning (debris and vegetation) of some large sites of La Rioja. The number of footprints is those currently visible and deducible (Barranco de Valdegutiérrez site).

\begin{tabular}{lccc}
\hline \multicolumn{1}{c}{ Sites } & $\begin{array}{c}\text { present } \\
\text { extension }\end{array}$ & expandable to & footprints \\
\hline $\begin{array}{l}\text { La Canal-Peñaportillo }+ \\
\text { La Pellejera + Los Cayos } \\
+ \text { La Virgen del Campo }\end{array}$ & $8,200 \mathrm{~m}^{2}$ & $23,200 \mathrm{~m}^{2}$ & 4,988 (now) \\
+ El Peladillo & & & \\
$\begin{array}{l}\text { Barranco de } \\
\text { Valdegutiérrez }\end{array}$ & 0 & $31,000 \mathrm{~m}^{2}$ & $>10,000$ \\
\hline
\end{tabular}

In an unexcavated area of $31,000 \mathrm{~m}^{2}$ called Barranco de Valdegutiérrez (Jiménez-Vela \& Pérez-Lorente, 2005) the most favourable calculations give a population of more than 10,000 footprints. This means that, according 
to previous data, with appropriate excavation campaigns (the same system that we have used in previous years) about 20,000 new footprints could be revealed in less than 10 years.

\section{PALAEONTOLOGICAL HERITAGE OF LA RIOJA}

\subsection{Declaration and legal protection}

The number of sites and footprints in the region has become significant over the years. The lack of control, commercialism, and collection has resulted in the theft of some footprints, others being broken in the attempt, and some incidental destruction (for example Los Cayos $\mathrm{D}$ was destroyed during the construction of a new road). A piece of the Igea fossil trunk was even stolen in 1985, and according to unconfirmed rumours dinosaur footprints were sold in a village in the region around 1980 .

To prevent the destruction of sites with dinosaur footprints, the Departamento de Medio Ambiente in 1988 proposed a Special Plan for the Protection of the Environment of La Rioja (PEPMA), which included a number of sub-plans with protection measures based on land use. Among the sub-plans was the Special Plan for the Ichnite Protection of La Rioja (PEPIR). In 1994 (Resolution 05.12.1994) the places with dinosaur footprints were classified in the PEPIR as "Áreas de Protección Especial, Zonas de Interés, Itinerarios de Interés, and Áreas de Expansión", leaving the Cameros sector of La Rioja subject to protective measures. The government of La Rioja considered the footprints to be part of the regional heritage and stated that the administrative section responsible for the cultural heritage also included the paleontological heritage (Decree 91/1995 Regulation of administrative authority). In connection with the above measures, an inventory card of each of the known sites was commissioned by the Dirección General de Cultura, whose data recorded the extent, the footprint content, and the conservation state of each site.

In 1997, work began to include La Rioja dinosaur footprints in the List of World Heritage Sites. The inventory and cataloguing of all the sites in the La Rioja Cameros Basin were prepared, and the footprint localities grouped into 40 integrated sites, declared Bienes de Interés Cultural (BIC), within the denomination of Sitios Históricos (Decree 34/2000). The request for La Rioja dinosaur footprints to be considered as World Heritage was extended in 1998 to other autonomous regions (Principado de Asturias, Castilla y León, La Rioja, Aragón, Cataluña and Comunidad Valenciana), and submitted for evaluation as World Heritage in 2006. Finally, Portugal joined the proposal (Icnitas de Dinosaurios de la Península Ibérica project) and the new candidature was presented in 2010. This request was rejected by the UNESCO both times.

\subsection{The evaluation criteria of the La Rioja tracksites}

One difference between inventory and catalogue is that the latter includes the evaluation of the sites. Each site was assessed in the catalogue made for the BIC declaration. Since the many value scales on geological resources are made on different bases, an scale of its own was proposed and presented at a meeting of the Comisión de Patrimonio Geológico (Caro \& Pérez-Lorente, 1997). The scale, which considers only the scientific content, is based on the object (the footprints, the trackway, the association of footprints and trackways) and ichnological interest (originality and uniqueness). This scale has not taken into account other aspects because they are not relevant for the purposes of this assessment. However, there are characteristics such as the state of conservation, vulnerability, access, and visual impact that are essential in assessments made for other purposes. Entirely subjective assessments were made on the state of conservation of the sites, at least for the three groups working for the La Rioja government.

The outcrops with more than three tracks were inventoried and catalogued in the list of BIC, whereas many known outcrops with less than three dinosaur footprints were not inventoried. The whole territory, however, is protected by the PEPIR and by the Historical and Artistic Heritage Law of La Rioja (11/2005).

\subsection{Physical protection of palaeoichnological heritage}

All sites were in open fields and access was granted to all visitors, who walked over them, even rode bicycles. The tracks were marked with contour lines; efforts were made to take them or other fossils, especially bivalve shells, or to take moulds with plaster or cement. Individual reports of theft or wrongdoing were not confirmed in written reports or endorsed by signatures. Part of this was corrected after the creation of the Palaeontological Heritage Foundation of La Rioja, which sought to verify allegations and guard against recurrence of the infractions. Vandalism and works without permission from the Dirección General de Cultura are investigated by two different bodies: the Seprona and the forest ranger service.

To avoid or minimize damage, physical protection of the sites was undertaken, including: a) preparation of sites that most attract visitors; b) treatment and protection for conservation of rock surfaces with footprints; c) outreach. 


\subsubsection{Roofs and fences}

The first work of protection was the construction of a fence around theropod dinosaur footprints on Barranco de Valdecevillo site in 1976. This construction, made by the Iberduero Company, consisted of an iron fence around four deep theropod footprints (VA4 trackway). This fence has been kept because it suggests a reserved space, and because it is a barrier to the passage of mountain vehicles (bicycles and motorcycles) over the footprints. Fences have been built as well as walkways and enclosed areas at various sites (Era del Peladillo, Los Cayos, El VillarPoyales, Barranco de Valdecevillo, La Senoba, La Virgen del Campo, Las Losas, Peñaportillo, and Barranco de la Canal). Most of the fences and walkways are wooden and rest directly on the rock without being anchored or with works affecting the strata. There are wooden elevated viewpoints in the Era del Peladillo, La Senoba, La Virgen del Campo and Barranco de La Canal.

The experience in La Rioja, as in other parts of the world, indicates that roofs and similar constructions protect the beds and footprints. Neither rain nor snow fall directly on the rock. Roofs also provide protection from the sun, preventing plant life, and decreasing the magnitude of diurnal temperature variation of the rock. The sun can heat the rock during the summer to temperatures above $40^{\circ} \mathrm{C}$ in places whereas at night they drop below $20^{\circ} \mathrm{C}$.

In 1998, the government of La Rioja opened a contest of ideas looking for a project to choose a unified type of building to protect the sites from inclement weather, the entry of animals, and deterioration caused by visitors while inviting the visits. Since none of the projects met the above requirements, the government put out to tender the construction of a fence with a roof at the site of Peñaportillo in 1999. This type of protective action was meant to be continued and, upon completion of the above, the government called for offers to carry out the construction of another at Las Navillas site. As no offers were presented, the project was cancelled.

In other construction works, some of them uncontrolled, shed roofs were made in Los Cayos, Icnitas 3 (a part of El Villar-Poyales site) and VA4 (a trackway of Barranco de Valdecevillo site).

\subsubsection{Rock conservation}

The sites are under destruction due to atmospheric and biological agents. The exposed rocks are weathered, colonized by plants and finally eroded. Since 2001 the Direction of Culture (government of La Rioja) has not granted permission for digging dinosaur footprints due to the current destruction of the tracks. The purpose of the work camps, which at first were for digging, changed to conservation. We have worked systematically at various sites for their repair and maintenance.
The work is not restoration seeking to remake the original form, or protection with impregnation (strengtheners, water repellents), but conservation of the current state. The purpose is to clean the cracks of clay and debris that occupied them, remove plants, stick together loose fragments, and fill the visible gaps. The edges of layers with footprints, from which fragments were coming loose, have been consolidated, and have also been waterproofed to keep out rainwater.

Clay and debris fillings of separated rock spaces (especially joints), and the vegetation that colonizes them are mechanically removed. Part of the working utensils is prepared in the same work site with iron or plastic rods, and wire, which are given the appropriate shape. The gaps are filled and the rock fragments are stuck with resin, silicone, and mortar that have previously been tested (Caro \& Pavia, 1998). No products are applied by impregnation because water penetration, variations in temperature and the action of the sun's rays cannot be controlled on the rock and the products after application. Herbicides that could pollute the site and the surroundings have not been used, either.

\subsection{Outreach}

Information to the public has been disseminated in several ways: the media; scholarly and popular publications; leaflets on the right places to visit; placement of dinosaur models; theoretical and practical training of guides; and summer courses, work camps and lectures in the villages concerning the footprint sites.

Since 1979, the year in which the team of Brancas, Blaschke and Martínez painted several dinosaurs on a wall of a stratum, several reproductions of dinosaurs have been placed on the site. The first model, in 1981, was a sculpture of plaster over a wooden frame, made by the association of Amigos de Poyales, who wanted it to represent a carnivorous dinosaur. Nothing remains of the paintings, or of that theropod dinosaur. In 1991 a Tarbosaurus based on an outdated figure from a dinosaur book was set up. Other sculptures have followed this one, more or less faithful to the existing models. Outdoors stand seven iguanodonts, two mantelisaurs, an ornithopod semiplantigrade dinosaur, two theropods, one Brachiosaurus and one Stegosaurus. In two palaeontololgical centres, stand two Baryonyx models and an Iguanodon shows its entrails.

The first camp works, in 1980, were similar to an excavation made by a research team. That is, a group of teachers and students worked without rules other than those imposed by the director of the excavation. With this same system, but open to all visitors, the activities continued until they became university-programmed activities. At one excavation, five summer work camps and three summer courses were held, regulated by the university. Two work camps were international camps regulated by the Instituto 
de la Juventud of the Government of La Rioja. The courses and summer camps were announced with posters in all Spanish universities, most European universities with geology studies, and many others around the world. They have also been made public by the usual means of universities (summer courses) and youth associations (international work camps). The activities were drastically reduced in 2014 and university activity ceased in 2015.

Other activities of scientific outreach have included annual series of lectures by invited researchers and professionals from different fields: dinosaurs, palaeontological and natural heritage, rock restoration, and protected natural areas.

\subsection{Social exploitation}

Since the first excavation campaigns, the number of visitors has grown steadily, perhaps due to news reports. Summer courses and work camps on La Rioja dinosaur footprints have been the subject of headlines in the newspapers during the summers of over 30 years. Tourism has affected the economy of several towns, manifested in the opening of restaurants, bars, inns, and guesthouses.

First the government of La Rioja, and later the former Cajarioja Foundation participated, so that the government published three small monographs (Brancas et al., 1979; Pérez-Lorente et al., 1986; Moratalla et al., 1988). Thanks to the collaboration of the two institutions, several sites were adapted for visits, by means of fences, information boards, the publication of brochures and the preparation of roads. In 1997, the Centro Paleontológico de Enciso was opened and in 1998 the Fundación Patrimonio Paleontológico de La Rioja was created. Later, on the initiative of the municipality of Igea, the Cento Paleontológico de Igea was opened in 2003. Since 2013 the Centro Paleontológico de Enciso has been closed to the public with no other activity apart from storing documents and palaeontological material. In Arnedo there is also a city museum in which fossils and minerals have been kept since 1975.

The Fundación Patrimonio Paleontológico, whose board also included the Direccion de Turismo of the La Rioja government, began to take initiatives in this field by establishing three palaeontological routes, which were indicated, matching the valleys of three rivers (Alhama, Cidacos, Leza). The Fundación Patrimonio Paleontológico was dissolved in 2013.

Finally a park based on dinosaurs, "El Barranco Perdido", was built in Enciso in 2009. This park exhibits dinosaurs and their footprints (replicas and originals), excavation and recognition activities of dinosaur footprints on replica sites, film and theatre sessions, pools with reproductions of the dinosaurs and their world, and an area of adventure primarily directed to children and youth. This park is open to visitors from April to September.

\section{CONCLUSIONS}

The dinosaur footprints of La Rioja constitute a resource for palaeontological research that has provided results of scientific interest concerning dinosaurs and their behaviour. Research is a cornerstone of this ensemble. Nevertheless, its interdependence with popular science, tourism, and the cooperation between institutions and various groups, has been crucial in the activation of the economy and thus the maintenance of human populations, the existence of resources to investigate, and the promotion of parallel activities. These activities of dissemination and social outreach (university courses of palaeoichnology and conservation of sites, and lectures) can be used to accelerate the pace of research and protection, and to maintain an external quality control.

\section{ACKNOWLEDGMENTS}

The work done in La Rioja would not have been possible without the contributions of many institutions and groups. The main contribution to the team that I represent was from the Instituto de Estudios Riojanos which created and funded for several years the research plans on dinosaur footprints, the annual conferences of Enciso, and published in its Zubía review and book collection of Ciencias de la Tierra all dinosaur footprint research and geological aspects related to them that had previously been accepted by two anonymous reviewers. The latest research campaigns were funded by the Fundación Patrimonio Paleontológico de La Rioja, Fundación de la Universidad de La Rioja and the Fomenta plans of the Government of La Rioja.

Work camps and summer courses have been successively funded by the Consejería de Cultura, the Colegio Universitario de Logroño and the universities of Zaragoza and La Rioja, and finally by the group of Universidad de La Rioja, the Fundación Patrimonio Paleontológico de La Rioja, and Instituto Riojano de Junventud. The former Fundación Cajarioja played an active role in the commencement of tourism development in the area including cash contributions. It also participated in the opening of Centro Paleontológico de Enciso, the creation of the Fundación Patrimonio Paleontológico de La Rioja and in obtaining funds for adaptation of the sites.

I would thank the people who have held positions in the institutions both during the progress and the maintenance of activities. In my opinion, the progress made during this time has been thanks to them.

Finally, I must acknowledge the work of more than 2,000 students participating in the work camps (excavation, data collection, preservation), the collaboration of the municipalities of Enciso, Igea and Hornillos de Cameros, 
the associations Rastros, Amigos de Poyales and Amigos del Museo de Enciso, and the collaboration of many people. For example, Mercedes Marin, a shopkeeper in Enciso, now retired, lent us her phone in order for students to speak with their family, reverse charge, and sold us the food and drink on credit during the campaigns until the administration reimbursed us.

\section{REFERENCES}

Aguirrezabala, L.R. \& Viera, L.J. 1980. Icnitas de dinosaurios en Bretún (Soria). Munibe, 3-4, 257-279.

Aguirrezabala, L.R., Torres, J.A. \& Viera, L.I. 1985. El weald de Igea (Cameros. La Rioja). Sedimentología, bistratigrafía y paleontología de grandes reptiles (Dinosaurios). Munibe, 37, 111-118.

Alexander, R.M. 1976. Estimates of speed of dinosaurs. Nature, 261, 129-130; doi: 10.1038/261129a0.

Allen, J.R.L. 1997. Subfossil mammalian tracks (Flandrian) in the Severn Estuary S.W. Britain: mechanics of formation, preservations and distribution. Philosophical Transactions of the Royal Society of London B, 352, 481-518; doi: 10.1098/rstb.1997.0035.

Baird, D. 1952. Revision of Pensilvanian and Permian footprints Limnopus, Allopus and Baropus. Journal of Paleontology, 76, 832-840.

Boutakiout, M., Hadri, H., Nouri, J., Caro, S. \& PérezLorente, F. 2006. The syngenetic structure suite of dinosaur footprints in finely laminated sandstones. Site $\mathrm{n}^{\mathrm{o}} 1$ of Bin El Ouidane (1BO; Central Atlas, Morocco). Ichnos, 13, 39-42; doi: 10.1080/10420940600739781.

Brancas, R., Martínez, J. \& Blaschke, J. 1979. Huellas de Dinosaurio en Enciso. Diputación de Logroño, Colección Gonzalo de Berceo, 2.

Brown, T. 1999. The Science and Art of Tracking. Berkeley Books, Nueva York.

Caro, S. \& Pavía, S. 1998. Alteración y conservación de los yacimientos de huellas de dinosaurio de La Rioja. "La Virgen del Campo" (Enciso) y "La Era del Peladillo" (Igea). Zubía, 16, 199-232.

Caro, S. \& Pérez-Lorente, F. 1997. Definición de concepto y propuesta de valoración del patrimonio paleoicnológico (pisadas de dinosaurio) de La Rioja. II Reunión de la Comisión de Patrimonio Geológico. Zubía, 15, 39-43.

Casamiquela, R.M. 1964. Estudios Icnológicos. Problemas y Métodos de la Icnología con Aplicación al Estudio de Pisadas Mesozoicas (Reptilia, Mammalia) de la Patagonia. Publicaciones del Ministerio de Asuntos Sociales. Rio Negro. Argentina.

Casanovas, M.L. \& Santafé, J.V. 1971. Icnitas de reptiles mesozoicos en la provincia de Logroño. Acta Geologica Hispanica, 6, 139-142.

Casanovas, M.L. \& Santafé, J.V. 1974. Dos nuevos yacimientos de icnitas de reptiles mesozoicos en la región de Arnedo. Acta Geologica Hispanica, 9, 88-91.
Casanovas, M.L., Santafé, J.V. \& Sanz, J.L. 1984. Las icnitas de "los Corrales del Pelejón" en el Cretácico inferior de Galve (Teruel, España). Paleontologia i Evolució, 28, 173-176.

Casanovas, M.L., Fernández, A., Pérez-Lorente, F. \& Santafé, J.V. 1989. Huellas de Dinosaurios de La Rioja. Yacimientos de Valdecevillo, La Senoba y de la Virgen del Campo._Instituto de Estudios Riojanos. Logroño. Colección Ciencias de la Tierra 12.

Casanovas, M.L., Fernández, A., Pérez-Lorente, F. \& Santafé, J.V. 1991. Dinosaurios coelúridos gregarios en el yacimiento de Valdebrajés (La Rioja. España). Revista Española de Paleontología, 6, 177-189.

Casanovas, M.L., Ezquerra, R., Fernández, A., Pérez-Lorente, F., Santafé, J.V. \& Torcida, F. 1993a. Tracks of a herd of webbed ornithopods and other footprints found in the same site (Igea, La Rioja, Spain). Revue de Paléobiologie, 7, 37-44.

Casanovas, M.L., Ezquerra, R., Fernández, A., Pérez-Lorente, F., Santafé, J.V. \& Torcida, F. 1993b. Icnitas digitígradas y plantígradas de dinosaurios en el afloramiento de El Villar-Poyales. (La Rioja. España). Zubía (Monográfico), 5, 135-163.

Casanovas, M.L., Ezquerra, R., Fernández, A., PérezLorente, F., Santafé, J.V. \& Torcida, F. 1993c. Icnitas de dinosaurios. Yacimientos de Navalsaz, Las Mortajeras, Peñaportillo, Malvaciervo y la Era del Peladillo 2. (La Rioja. España). Zubía (Monográfico), 5, 9-133.

Casanovas, M.L., Ezquerra, R., Fernández, A., Montero, D., Pérez-Lorente, F., Santafé, J.V., Torcida, F. \& Viera, L.V., 1995. El yacimiento de La Canal (Munilla, La Rioja. España). La variación de velocidad en función del tamaño del pie de los ornitópodos. Zubía, 13, 55-81.

Casanovas, M.L., Fernández, A., Pérez-Lorente, F. \& Santafé, J.V. 1997. Sauropod trackways from site El Sobaquillo (Munilla, La Rioja, Spain) indicate amble walking. Ichnos, 5, 101-107.

Costeur, L., Domenici, P., Ezquerra, R., Rousseau, M., Antognarelli, F., Satta, A., Simeone, S. \& Pérez-Lorente, F. 2011. A Cretaceous fish takes a fast start: insights from a recent analogue. $9^{\text {th }}$ Swiss Geoscience Meeting, Zurich, 1-3.

Demathieu, G.R. 1970. Les empreintes de pas de vertebrés du trias de la bordure nord-est du Massif Central. Cahiers de Paleontologie, 11, 1-219.

Demathieu, G.R. 1980. Use of trace fossils for interpretation of triassic depositional environments northeast border of French Massif Central, France. American Association of Petroleum Geologists Bulletin, 64, 697-698.

Demathieu, G.R. 1986. Nouvelles recherches sur la vitesse des vertébrés, auteurs de traces fossiles. Geobios, 19, $327-$ 333; doi: 10.1016/S0016-6995(86)80021-3.

Demathieu, G.R. 1986. La notion d'ichnogenre dans le domaine de la palichnologie des Vertébrés. Bulletin de Sciences. Université de Bourgogne, 39, 61-69.

Demathieu, G.R. 1987. Apparent limbs. In: Glossary and Manual of Tetrapod Footprint Palaeoichnology (ed. Leonardi, G.), p. 59. 
Díaz-Martínez, I. 2013. Icnitas de dinosaurios bípedos de La Rioja (Cuenca de Cameros. Cretácico Inferior). Icnotaxonomía y aplicación paleobiológica. Ph.D. Thesis, Universidad de La Rioja (unpublished).

Doublet, S. 2004. Controles tectonique et climatique de l'enregistrement stratigraphique dans un basin continental de rift: le basin de Cameros. Ph.D. Thesis,Université de Dijon (Francia) (unpublished).

Ellenberger, P. 1974. Contribution a la classification des pistes de vertebrés du Trias: les types du Stormberg d'Afrique du Sud (II ${ }^{\mathrm{eme}}$ partie: le Stromberg superieur. I Le biome de la zone $\mathrm{B}_{11}$ au niveau de moyeni: ses biocenosis). Palaeovertebrata, Memoire Extraordinaire, 1-170.

Ezquerra, R. \& Pérez-Lorente, F. 2003. Reptiles nadadores en el sector oeste del yacimiento de la Virgen del Campo (4LVC, Enciso. La Rioja. España). In: Dinosaurios y Otros Reptiles Mesozoicos de España (coord. Pérez-Lorente, F.). Instituto de Estudios Riojanos, Ciencias de la Tierra, 26, 215-224.

Ezquerra, R., Doublet, S., Costeur, L., Galton, P.M. \& PérezLorente, F. 2007. Were non-avian Theropod dinosaurs able to swim? Supportive evidence from an Early Cretaceous trackway, Cameros Basin (La Rioja, Spain). Geology, 35, 507-510; doi: 10.1130/G23452A.1.

Fornós, J.J., Bromley, R.G., Clemensen, L.B. \& RodríguezPérez, A. 2002. Tracks and trackways of Myotragus balearicus Bate (Artiodactyla, Caprinae) in Pleistocene aeolianites from Mallorca (Balearic Islands, Western Mediterranean). Palaeogeography, Palaeoclimatology, Palaeoecology, 180, 277-313; doi: 10.1016/S00310182(01)00431-X.

Gámez, J.A. \& Belinchón, M. 2013. Análisis crítico de la "icnita" de Arroyo Cerezo, primera huella de dinosaurio descrita en España. XXIX Jornadas de Paleontología, 79-90.

García Hernández, M. 1978. El Jurásico terminal y el Cretácico inferior en las Sierras de Cazorla y Segura (Zona Prebética). Ph.D. Thesis, Universidad de Granada, (unpublished)

García-Ortiz, E. \& Pérez-Lorente, F. 2014. Palaeoecological inferences about dinosaur gregarious behaviour based on the study of tracksites from La Rioja area in the Cameros Basin (Lower Cretaceous, Spain). Journal of Iberian Geology, 40, 113-127.

García-Raguel, M., Cuevas, I., Díaz-Martínez, I. \& PérezLorente, F. 2009. Fragmentos de roca con huellas de ave en el terciario de Alcanadre (La Rioja). Descripción, estructuras y problemas de identificación. Zubía, 27, 81-158.

García-Ramos, J.C. 1975-76. Hallazgo de huellas de dinosaurios (Theropoda y Ornithopoda) en la costa asturiana. Astunatura, 3, 171-172.

Gatesy, S.M. 2003. Direct and indirect tracks features: what sediment did a dinosaur touch? Ichnos, 10, 91-98; doi: 10.1080/10420940390255484.

Gatesy, S.M., Middleton, K.M., Jenkins, F.A.J. \& Shubin, N.H. 1999. Three-dimensional preservation of foot movements in Triassic theropod dinosaurs. Nature, 399, 141-144; doi: 10.1038/20167.
Haubold, H. 1971. Ichnia amphibiorum et reptiliorum fossilia. In: Handbuch der Paläoherpetologie, (ed. Kuhn, O.). 18, $1-124$

Hernández Medrano, N., Requeta, E. \& Pérez-Lorente,F. 2006. La Pellejera, ejemplo de nuevos yacimientos icníticos en Cameros (La Rioja-Soria. España) In: Actas III Jornadas Internacionales. Paleontología de Dinosaurios y su Entorno (2004). (ed. Colectivo Arqueológico Salense), 235-252.

Heyler, D. \& Lessertisseur, J. 1963. Pistes de tétrapodes permiens dans la région de Lodève (Hérault). Mémoire du Muséum national d'Histoire naturel de Paris. Série C. Sciences de la Terre, 11, 9-221.

Hitchcock, E. 1836. Ornithichnology. Description of the foot marks of birds (Ornithoid ichnites) of New Red Sandstone in Massachusetts. American Journal of Science, 29, 307-340.

Hitchcock, E. 1858. Ichnology of New England. A Report on the Sandstone of the Connecticut Valley, Especially its Fossil Footmarks._William White, Boston, Massachusetts.

Jiménez Vela, A. \& Pérez-Lorente, F. 2005. A new great dinosaur footprint site: Barranco de Valdegutiérrez (La Rioja. Spain). International Symposium on Dinosaurs and other Vertebrates Palaeoichnology. Abstract book, p. 37.

Lapparent, A.F., Le Joncour, M., Mathieu, A. \& Plus, B. 1965. Découverte en Espagne d'empreintes de pas de reptiles mésozoïques. Boletín de la Real Sociedad Española de Historia Natural (Geología), 63, 225-230.

Leonardi, G. (ed.). 1987. Glossary and Manual of Tetrapod Footprint Palaeoichnology, Departamento Nacional da Produção Mineral, Brasilia.

Llompart, C. 1979. Yacimiento de huellas de pisadas de reptil en el Cretácico superior pre pirenaico. Acta Geologica Hispanica, 14, 333-336.

Lockley, M.G. 1991. Tracking Dinosaurs: A New Look at an Ancient World. Cambridge University Press.

Lockley, M.G., Hunt, A.P., Moratalla, J.J. \& Matsukawa, M. 1994. Limping dinosaurs? Trackway evidence for abnormal gaits. Ichnos, 3, 193-202; doi: 10.1080/10420949409386388.

Lockley, M.G., Santos, V.F. dos, Meyer, C. \& Hunt, A. 1998. A new dinosaur tracksite in the Morrison Formation, boundary Butte, southeastern Utah. Modern Geology, 23, 317-330.

Lull, R.S. 1953. Triassic life of the Connecticut Valley (revised) State of Connecticut. Connecticut State Geological and Natural History Survey Bulletin, 81, 1-336.

Manning, P.L. 2004. A new approach to analysis and interpretation of tracks: examples from the Dinosauria. In: The Application of Ichnology to Palaeoenvironmental and Stratigraphic Analysis, (ed. McIlroy, D.), Geological Society Special Publication, 228, 93-123.

Moratalla, J.J. 1993. Restos indirectos de dinosaurios del registro español: paleoicnología de la Cuenca de Cameros (Jurásico superior-Cretácico inferior) y paleoología del Cretácico superior. Ph.D. Thesis Universidad Autónoma. Madrid (unpublished).

Moratalla, J., Sanz, J. \& Jiménez, S. 1988. Nueva evidencia icnológica de dinosaurios en el Cretácico inferior de La Rioja (España). Estudios Geológicos, 44, 119-131. 
Moratalla, J., Sanz, J., Melero, I. \& Jiménez, S. 1988. Yacimientos Paleoicnológicos de La Rioja (Huellas de Dinosaurios). Iberduero.

Moratalla, J.J., García-Mondéjar, J., Santos, V.F., Lockley, M.G., Sanz, J.L. \& Jiménez, S. 1994. Sauropod trackway from the Lower Cretaceous of Spain. Gaia, 10, 75-83.

Peabody, F.E. 1948. Reptile and amphibian trackways from the lower Triassic Moenkopi Formation of Arizona and Utah. Bulletin Department of Geological Sciences, University of California, 27, 295-468.

Peabody, F.E. 1955. Taxonomy and the footprints of tetrapods. Journal of Paleontology, 29, 915-918.

Peabody, F.E. 1959. Trackways of living and fossil salamanders. University of California Publications in Zoology, 63, 1-72.

Pérez-Lorente, F., 2001. Paleoicnología. Los Dinosaurios y sus Huellas en La Rioja. Gobierno de La Rioja.

Pérez-Lorente, F. 2002. La distribución de yacimientos y de tipos de huellas de dinosaurio en la Cuenca de Cameros (La Rioja, Burgos, Soria. España). In: Aspectos Naturalísticos de los Cameros. I Geología, (coord. PérezLorente, F.), Zubía (Monográfico), 14, 191-220.

Pérez-Lorente, F. 2003a. Icnitas de dinosaurios del Cretácico de España. In: Dinosaurios y otros Reptiles Mesozoicos de España (coord. Pérez-Lorente F.), Instituto de Estudios Riojanos, Ciencias de la Tierra, 26, 49-108.

Pérez-Lorente, F. 2003b. Aportaciones de los yacimientos de Las Barguillas, Santisol y Santa Juliana (Hornillos de Cameros, La Rioja, España). In: Dinosaurios y otros Reptiles Mesozoicos de España (coord. Pérez-Lorente F.), Instituto de Estudios Riojanos, Ciencias de la Tierra, 26, 161-194.

Pérez-Lorente, F. 2015. Dinosaur Footprints and Trackways of La Rioja. Indiana University Press.

Pérez-Lorente, F., Guillén-Mondejar, F. \& Del Ramo, A. 2006. Primeras icnitas de dinosaurio en Murcia (Albiense de Yecla). Geogaceta, 39, 147-150.

Pérez-Lorente, F., Fernández, A. \& Uruñuela, L. 1986. Pisadas Fósiles de Dinosaurios. Algunos Ejemplos de Enciso. Gobierno de La Rioja.

Pérez-Lorente, F., Romero-Molina, M.M., Requeta, E., Blanco, M. \& Caro, S. 2001. Dinosaurios. Introducción y Análisis de Algunos Yacimientos de sus Huellas en La Rioja. Instituto de Estudios Riojanos, Ciencias de la Tierra, 24.

Razzolini, N.I., Vila, B., Díaz-Martínez, I., Pérez-Lorente, F., Manning, P.L. \& Galobart, A. 2015. Alternating pes morphologies in a long ornithopod (Dinosauria) trackway. First International Congress in Continental Ichnology. Proceeding of abstracts. p.55.
Requeta, L.E., Hernández Medrano, N. \& Pérez-Lorente, F. 2006-7. La Pellejera: Descripción y aportaciones. Heterocronía y variabilidad de un yacimientos con huellas de dinosaurio de La Rioja (España). Zubía (Monográfico), 18-19, 21-114.

Romano, M. \& Whyte, M.A. 2012. Information on the foot morphology, pedal skin texture and limb dinamics of sauropods: evidence from the ichnological record of the Middle Jurassic of the Cleveland Basin, Yorkshire, UK. Zubia, 30, 45-92.

Romero-Molina, M.M., Pérez-Lorente, F. \& Rivas, P. 2001. Estructuras asociadas con huellas de dinosaurio en La Rioja (España). Zubía, 19 61-96.

Romero-Molina, M.M., Pérez-Lorente, F. \& Rivas, P. 2003a. Análisis de la parataxonomía utilizada con las huellas de dinosaurio. In: Dinosaurios y otros Reptiles Mesozoicos de España (coord. Pérez-Lorente, F.), Instituto de Estudios Riojanos, Ciencias de la Tierra, 26, 13-32.

Romero-Molina, M.M., Sarjeant, W.A.S., Pérez-Lorente, F., López, A. \& Requeta, E. 2003b. Orientation and characteristics of theropod trackways from the Las Losas Palaeoichnological site (La Rioja, Spain). Ichnos, 10, 241254; doi: 10.1080/10420940390255529.

Sarjeant, W.A.S. 1989. “Ten paleoichnological commandments": a standardized procedure for the description of fossil vertebrate footprints. In: Dinosaur Tracks and Traces (eds Gillette, D.D. \& Lockley, M.G.). Cambridge Univ. Press, 369-370.

Sarjeant, W.A.S. 1990. A name for the trace of an act: approaches to the nomenclature and classification of fossils vertebrate footprints. In: Dinosaur Systematics. Perspectives and Approaches (eds Carpenter, K. \& Currie, P.J.). Cambridge Univ. Press, 299-308.

Sternberg, C.M. 1926. Dinosaur tracks from the Edmonton Formation of Alberta. Geological Survey Bulletin, Canada Department of Mines, 44, Geological Series, 46, 85-87.

Thulborn, R.A. 1990. Dinosaur Tracks. Chapman and Hall.

Thulborn, R.A. \& Wade, M. 1989. A footprint as a history of movement. In: Dinosaur Tracks and Traces_(eds_Gillette, D.D. \& Lockley, M.G.). Cambridge University. Press, $51-56$.

Tischer, G. 1966. Über die Wealden-Ablagerung und die Tektonik der östlichen Sierra de los Cameros in den nordwestlichen Iberischen Ketten (Spanien). Geologisches Jahrbuch, 44, 123-164.

Viera, L.I. \& Torres, J.A. 1979. El Weáldico de la zona de Enciso (Sierra de los Cameros) y su fauna de grandes reptiles. Munibe 31, 141-157. 
